JURNAL

MANAJEMEN PENDDIKAN Vol. 5 No.2 Maret 2021: pp.61-66

PENELITIAN KUALITATIF

e-ISSN: 2775-6904 | p-ISSN: 2502-9487

RESEARCH ARTICLE

OPEN ACCESS

\title{
PROFIL KINERJA GURU MADRASAH TSANAWIYAH NEGERI 3 PEKANBARU
}

\author{
Rina Darmayanti ${ }^{1}$ \\ Sumardi ${ }^{2}$ \\ Nurpit Junus ${ }^{3}$ \\ ${ }^{1,2,3}$ Magister Administrasi Pendidikan Pascasarjana Universitas Riau
}

\begin{abstract}
This research is descriptive qualitative research. The technique of data collection was done through observation, interview and documentation. This research was conducted at MTs Negeri 3 Pekanbaru, the object of the research is to look at the profile of professional teacher performance.Research aims (1) to analyze the performance of teacher professional learning activities in drawing up the programme in MTs Negeri 3 Pekanbaru, (2) to analyze the performance of professional teachers in carrying out the activities of learning at MTs Negeri 3 Pekanbaru and (3) to analyze the performance of professional teachers in assessing any late learners learning in MTs Negeri 3 Pekanbaru. The respondents of the research was all the teachers who have been certified in MTs Negeri 3 Pekanbaru is 42 professional teachers. The results obtained from this research are (1) there are a number of professional teachers make mistakes in formulating indicators of learning and learning strategies that are not in accordance with the contents of the learning and also in the writing of time allocation in the syllabus found some errors that are not in compliance with the allocation of time each function, (2) Found a few professional teachers using model/approach to learning that is not in accordance with the the learning step (3) In giving assesment there are still few professional teachers in MTs Negeri 3 Pekanbaru use student worksheet question bank not assess students understanding in accordance with the new material is submitted.It can be seen from the annex to the assessment that is in the RPP does not correspond to the given exercise teacher to students.
\end{abstract}

Key words: Profile; Professional teacher performance; MTs Negeri 3 Pekanbaru

\begin{abstract}
Abstrak: Penelitian ini merupakan penelitian deskriptif kualitatif. Teknik Pengumpulan data dilakukan melalui observasi, wawancara dan dokumentasi. Penelitian ini dilakukan di Madrasah Tsanawiyah Negeri 3 Pekanbaru, object penelitian ini adalah untuk melihat profil kinerja guru profesional. Peneitian ini bertujuan (1) Untuk menganalisis kinerja guru profesional dalam menyusun program kegiatan pembelajaran di MTS Negeri 3 Pekanbaru,(2) Untuk menganalisis kinerja guru profesional dalam melaksanakan kegiatan pembelajaran di MTs Negeri 3 Pekanbaru, dan (3) Untuk menganalisis kinerja guru profesional dalam menilai setiap akhir pembelajaran peserta didik di MTs Negeri 3 Pekanbaru. Responden penelitian adalah semua guru yang sudah sertifikasi di Madrasah Tsanawiyah Negeri 3 Pekanbaru yang berjumlah 42 orang guru profesional. Hasil yang diperoleh dari penelitian ini adalah (1) Terdapat beberapa orang guru profesional yang melakukan kesalahan dalam merumuskan indikator pembelajaran dan menggunakan strategi pembelajaran yang tidak sesuai dengan isi dari perangkat pembelajaran dan juga dalam penulisan alokasi waktu didalam silabus ditemukan beberapa kesalahan yang tidak sesuai dengan alokasi waktu setiap pertemuan, (2) Ditemukan beberapa orang guru profesional yang menggunakan model/pendekatan pembelajaran yang tidak sesuai dengan langkah pembelajaran yang dipilihnya (3) Didalam memberikan penilaian masih terdapat beberapa orang guru profesional di MTs Negeri 3 Pekanbaru yang menggunakan LKS sebagai bank soal bukan menilai pemahaman siswa sesuai dengan materi yang baru disampaikan. Hal ini dapat dilihat dari lampiran penilaian yang ada di RPP tidak sesuai dengan latihan yang diberikan guru kepada siswa.
\end{abstract}

Kata Kunci: Profil; Kinerja Guru profesional; MTs Negeri 3 Pekanbaru 
JURNAL

MANAJEMEN PENDDIKAN Vol. 5 No.2 Maret 2021: pp.61-66

PENELITIAN KUALITATIF

\section{PENDAHULUAN}

Guru adalah pendidik profesional dengan tugas utama mendidik, mengajar, membimbing, mengarahkan, melatih, menilai, dan mengevaluasi peserta didik pada pendidikan anak usia dini jalur pendidikan formal, pendidikan dasar, dan pendidikan menengah. Seorang guru wajib memiliki kualifikasi akademik, kompetensi, sertifikasi pendidik, sehat jasmani dan rohani, serta memiliki kemampuan untuk mewujudkan tujuan pendidikan nasional. Saat ini pemerintah membuat program pengembangan kompetensi guru dengan melakukan program sertifikasi.

Mengingat posisi guru yang sangat penting dalam pendidikan maka sudah selayaknya ada perhatian khusus terhadap guru. Implementasi Undang-Undang Guru dan Dosen Nomor 14 Tahun 2005 menuntut guru untuk memenuhi kualifikasi akademik yaitu S1 atau D/Akta IV, memiliki seperangkat kompetensi secara integral holistik yaitu kompetensi pedagogik, kompetensi kepribadian, kompetensi profesional, dan kompetensi sosial. Kualifikasi akademik dan seperangkat kompetensi tersebutlah yang akan mengantarkan guru untuk mengikuti sertifikasi guna memperoleh tunjangan profesi dari pemerintah.

Guru dipandang sebagai suatu pekerjaan yang profesional. Makna profesional dapat dipandang dari tiga dimensi, yaitu expert (ahli) Seorang guru bisa disebut ahlinya apabila tidak hanya menguasai isi pengajaran yang diajarkan saja, tetapi juga mampu dalam menanamkan konsep mengenai pengetahuan yang diajarkan dan mampu menyampaikan pesan-pesan didik. Mengajar adalah sarana untuk mendidik, untuk menyampaikan pesan pesan didik. Guru yang ahli memiliki pengetahuan tentang cara mengajar (teaching is a knowledge), juga keterampilan (teaching is skill) dan mengerti bahwa mengajar adalah juga suatu seni (teaching is an art). Rasa tanggung jawab (Responsibility) orang yang bertanggung jawab harus mampu memberi pertanggung jawaban terhadap orang lain.

Guru yang profesional mempersiapkan diri sematang-matangnya sebelum melakukan proses pembelajaran. la menguasai apa yang diajarkannya dan bertanggung jawab atas semua yang disampaikan dan bertanggung jawab atas segala tingkah lakunya., dan sense of belonging/collegue (rasa kesejawatan).

Upaya untuk meningkatkan profesionalisme guru adalah melalui sertifikasi sebagai sebuah proses ilmiah yang memerlukan pertanggung jawaban moral dan akademis. Dalam issu sertifikasi, adanya suatu uji kelayakan dan kepatutan yang dijalani seseorang, terhadap kriteria krieria yang secara ideal telah ditetapkan. Sertifikasi dibutuhkan untuk mempertegas standar kompetensi yang harus dimiliki para guru dan dosen sesuai dengan bidang keilmuannya masing masing.

Guru yang profesional dan telah disertifikasi selayaknya memenuhi kinerja yang mengacu kepada standar kompetensi guru, maksudnya disini adalah suatu ukuran yang ditetapkan bagi seorang guru dalam menguasi seperangkat kemampuan agar berkelayakan menduduki salah satu jabatan fungsional guru dan sesuai bidang tugas dan jenjang pendidikannya, yang tercermin dalam kemampuan dan penguasaan proses belajar mengajar.

Kinerja guru dapat dilihat dari pelaksanaan guru dalam merencanakan pembelajaran, melaksanakan pembelajaran, dan mengevaluasi pembelajaran. Sehingga apabila guru telah melaksanakan kegiatan perencanaan, pelaksanaan, maupun evaluasi pembelajaran dengan baik dan sesuai aturan yang telah ditentukan maka guru tersebut dianggap memiliki kinerja yang baik.

Berdasarkan informasi yang didapat dari salah seorang guru yang mengetahui fenomena guru MTs Negeri 3 Pekanbaru ini banyak terdapat guru yang sudah bersertifikasi dan menerima uang tunjangan sertifikasi, tetapi enggan meningkatkan kualitas profesionalismenya. Banyak guru yang jam terbangnya sudah sangat tinggi, namun perangkat pembelajaran nya masih belum lengkap disamping itu metode pembelajaran yang dibuat dalam RPP kurang kreatif dan guru disini tidak bisa mengelola kelas .

Jika hal ini dibiarkan berlarut larut akan berakibat kepada siswa karena akan berpengaruh terhadap siswa itu sendiri dan dampak yang diperoleh siswa-siswinya adalah timbul rasa bosan dan kurang berminat hasil yang di peroleh siswa-siswinya kurang efektif dalam pelajaran yang sedang di ikutnya. Dampaknya kepada siswa-siswinya hilang semangat belajar,menurunnya nilai yang di peroleh siswa-siswinya, karakternya pun akan berpengaruh kepada siswa-siswi maka guru tersebut tidak dapat membangkitkan semangat siswa-siswi untuk belajar, karena terbukti membosankan. Guru seperti ini akan sangat merugikan pihak sekolah terutama siswa-siswi yang diajarkan dan sangat di sayangkan juga 
JURNAL

MANAJEMEN PENDWDKAN Vol. 5 No.2 Maret 2021: pp.61-66

PENELITIAN KUALITATIF

karena propesi gurunya tidak digunakan semaksimal mungkin atau tidak digunakan secara profesional profesional.

Dengan melihat kondisi dan latar belakang diatas bahwa masih terdapat guru Sekolah MTS Negeri 3 Pekanbaru ini yang belum memiliki kinerja yang baik dalam merencanakan pembelajaran, melaksanakan pembelajaran, dan mengevaluasi pembelajaran, dikarenakan administrasi dalam kegiatan belajar mengajar yang masih tidak lengkap. Maka penulis tertarik untuk meneliti tentang " Profil Kinerja Guru Profesional di MTS Negeri 3 Pekanbaru".

Menurut Supardi (2013) Indikator penilaian terhadap kinerja guru dilakukan terhadap tiga kegiatan pembelajaran di kelas yaitu: (1) Menyusun Program Kegiatan Pembelajaran,Tahap ini berhubungan dengan kemampuan guru menguasai bahan ajar. Kemampuan guru dapat dilihat dari proses penyusunan program kegiatan pembelajaran yang dilakukan yaitu mengembangkan silabus dan rencana pelaksanaan pembelajaran (RPP). Menurut Nana Syaodih (2003) perencanaan pembelajaran meliputi kegiatan memilih dan mengembangkan bahan pelajaran, merumuskan tujuan pembelajaran, merencanakan kegiatan pembelajaran, dan merencanakan penilaian.(2) Pelaksanaan Kegiatan Pembelajaran, Kegiatan pembelajaran di kelas merupakan inti penyelenggaraan pendidikan yang ditandai dengan adanya pengelolaan kelas, penggunaan media dan sumber belajar, dan penggunaan metode serta strategi pembelajaran. Pelaksanaan pembelajaran harus mencakup membuka, melaksanakan, dan menutup pelajaran. Tugas tersebut merupakan tanggung jawab guru yang secara optimal dalam pelaksanaan menuntut kemampuan guru.(3) Penilaian Pembelajaran, Penilaian hasil belajar adalah kegiatan yang ditujukan untuk mengetahui tercapai atau tidaknya tujuan pembelajaran. Pada tahap ini guru dituntut memiliki kemampuan dalam menentukan pendekatan dan cara-cara evaluasi, penyusunan alat-alat evaluasi, pengolahan, dan penggunaan hasil evaluasi. Dengan demikian, melalui evaluasi atau penilaian pembelajaran, perkembangan siswa lebih terukur.

Dari uraian diatas penulis tertarik untuk untuk melakukan penelitian secara mendalam dan konperhensif tentang Profil Kinerja Guru Profesional di MTS 3 Tiga Pekanbaru dengan subfokus (1) Menyusun Program Kegiatan Pembelajaran, (2) Pelaksanaan Kegiatan Pembelajaran, (3) Penilaian Pembelajaran.

\section{METODOLOGI PENELITIAN}

Penelitian ini merupakan penelitian deskriptif kualitatif. Teknik Pengumpulan data dilakukan melalui (1) Observasi, Observasi merupakan teknik pengumpulan data dengan melihat dan mengamati langsung terhadap objek yang diteliti (Moleong, Lexy J. 2013). Tujuan nya ialah untuk melihat sikap dan prilaku keguruan yang dimiliki guru dalam interaksinya di dalam proses KBM,(2) wawancara digunakan untuk menghimpun atau mengumpulkan data-data dengan langsung mengadakan tanya jawab narasumber yang mengetahui persoalan dari objek yang diteliti. Tujuan dari wawancara itu sendiri adalah mendapatkan informasi dengan cara bertanya langsung kepada responden dan (3) dokumentasi tujuan nya ialah melengkapi data penelitian yang tidak didapatkan melalui wawancara maupun observasi. Dokumentasi ini berupa foto RPP dan hal yang berkaitan dengan kinerja guru.

Penelitian ini dilakukan di Madrasah Tsanawiyah Negeri 3 Pekanbaru, objek utama dalam penelitian ini adalah seluruh guru profesional yang ada di MTs Negeri 3 Pekanbaru yang berjumlah 42 orang guru.

\section{HASIL}

\section{Menyusun program kegiatan pembeajaran}

Guru profesional yang ada di MTs Negeri 3 Pekanbaru memahami pembuatan perencanaan pembelajaran seutuhnya, baik secara teoritis maupun praktis. Sesuai dengan hasil telaah dokumen dan dilihat dari hasil observasi ternyata masih ditemukan beberapa orang guru profesional yang melakukan berapa kesalahan dalam merumuskan indikator pembelajaran dan menggunakan strategi pembelajaran yang tidak sesuai dengan isi dari perangkat pembelajaran dan juga pada penulisan alokasi waktu disilabus juga ditemukan beberapa kesalahan. Seharusnya alokasi waktu yang dituliskan untuk satu kali pertemuan 
JURNAL

MANAJEMEN PENDWDIKAN Vol. 5 No.2 Maret 2021: pp.61-66
PENELITIAN KUALITATIF

gunanya agar guru bisa dengan mudah mengetahui batas pelajaran yang telah diberikan kepada peserta didik. Usaha dari pihak sekolah sebenarnya sudah cukup membantu para guru dalam meningkatkan kinerjanya, hal ini dapat dilihat dengan diberikannya pelatihan pelatihan yang berkenaan dengan pembuatan perangkat pembelajaran yang diadakan oleh pihak yang terkait. Perencanaan pembelajaran yang menjadi unsur utama dalam pembelajaran dan salah satu alat paling penting bagi guru yaitu menyusun Rencana Pelaksanaan Pembelajaran (RPP). Perencanaan pembelajaran sebenarnya merupakan salah satu kompetensi yang harus dimiliki guru. Kompetensi yang diamaksud adalah kompetensi pedagogik. Kompetensi dibidang pedagogik setidaknya guru memahami tentang tujuan pengajaran, cara merumuskan/memfomulasikan tujuan mengajar, memilih dan menentukan metode mengajar sesuai dengan tujuan yang hendak dicapai, memahami bahan pelajaran sebaik mungkin dengan menggunakan berbagai sumber, cara memilih, menentukan dan menggunakan alat peraga, cara membuat tes dan menggunakannya, dan pengetahuan tentang alat-alat evaluasi lainnya.

\section{Pelaksanaan Kegiatan Pembelajaran}

Guru profesional di MTs Negeri 3 Pekanbaru dalam melaksanakan kegiatan pembelajaran sudah cukup baik dalam memperhatikan kesesuaian materi dan strategi/ metode dalam pengajaran walaupun masih ditemukan beberapa orang guru profesional yang menggunakan model/pendekatan pembelajaran tidak sesuai dengan langkah pembelajaran yang dipilihnya. Didalam memilih media pembelajaran guru juga mempertimbangkan seberapa jauh media tersebut ampuh mengembangkan kemampuan atau perilaku yang tekandung dalam rumusan tujuan pembelajaran yang akan dicapai. Disamping itu pemilihan materi pembelajaran juga harus memperhatikan kesesuaian dengan tingkat pendidikan/ perkembangan siswa pada umumnya dan juga teroganisasi secara sistematik dan berkesimanbungan.Materi pelajaran merupakan suatu bahan yang disajikan guru untuk diolah dan kemudian dipahami oleh siswa, dalam rangka pencapaian tujuan pembelajaran yang telah dirumuskan sesuai dengan kurikulum. Dengan kata lain materi pembelajaran merupakan salah satu unsur atau komponen yang penting dalam pencapaian tujuan pembelajaran. Disamping itu pemilihan metode dan media pembelajaran yang tepat juga sangat membantu guru dalam penyampaian materi ajar dan mencapai tujuan pembelajaran yang diinginkan. Tanpa adanya keselarasan antara materi dengan strategi/ metode dan media belajar mengajar yang tepat, sulit bagi siswa untuk memahami tujuan pembelajaran yang diinginkan. oleh karena itu diharapkan adanya kesesuaian antara tujuan pembelajaran, alat evaluasi, materi pembelajaran, strategi/ metode pembelajaran dan media yang digunakan dalam kegiatan belajar mengajar

\section{Penilaian Pembelajaran.}

Untuk mengetahui tercapai atau tidaknya tujuan pengajaran serta kualitas proses belajar mengajar yang telah dilaksanakan, perlu dilakukan suatu usaha penilaian terhadap hasil belajar siswa. Guru profesional di MTs Negeri 3 Pekanbaru memanfaatkan hasil penilaian secara efektif untuk mengidentifikasi kekuatan, kelemahan, tantangan dan masalah potensial untuk peningkatan keprofesian dalam menunjang proses pembelajaran. Sesuai dari hasil telaah dokumen dan observasi masih terdapat guru yang menggunakan LKS sebagai bank soal bukan menilai pemahaman siswa sesuai dengan materi yang baru disampaikan. Hal ini dapat dilihat dari lampiran penilaian yang ada di RPP tidak sesuai dengan latihan yang diberikan guru kepada siswa. Pada dasarmya hasil penilaian digunakan dalam penyempurnakan rancangan dan pelaksanaan pembelajaran dengan cara mendiskusikan dan meminta guru menjelaskan dengan menggunakan RPP. Guru mengidentifikasi topik/kompetensi dasar yang mudah, sedang dan sulit untuk kegiatan remedial dan pengayaan dan pada tiap pertengahan semester dan juga guru membuat laporan kemajuan dan hasil belajar peserta didik kepada orang tua, teman guru dan bagi peserta didik sebagai refleksi belajarnya.

\section{PEMBAHASAN}

\section{Menyusun program perencanaan pembelajaran}

Perencanaan program pembelajaran (RPP) harus sesuai dengan konsep pendidikan dan pengajaran yang dianut dalam kurikulum. Langkah perencanaan program pengajaran memegang 
JURNAL

MANAJEMEN PENDWDIKAN Vol. 5 No.2 Maret 2021: pp.61-66
PENELITIAN KUALITATIF

peranan penting karena menentukan langkah selanjutnya yaitu pelaksanaan dan evaluasi. Kinerja guru profesional di MTs Negeri 3 Pekanbaru ini sebenarnya sudah baik dalam membuat dan merancang perangkat pembelajaran, hal ini dapat dilihat dari hasil wawancara, observasi dan dokumentasi yang sudah sesuai dengan modul yang diberikan oleh kementerian pendidikan dan kebudayaan pada saat pelatihan yang diselenggarakan disekolah induk masing-masing walaupun masih ada beberapa orang guru profesional yang menyusun perangkat pembelajaran tersebut tidak sesuai dengan penyusunan yang sudah tersedia didalam modul pembuatan perangkat pembelajaran tetapi guru profesional tersebut bisa menyeimbangi dalam memilih media pembelajaran untuk mencapai tujuan pembeajaran yang diinginkan.

\section{Pelaksanaan kegiatan pembelajaran}

Agar kegiatan belajar mengajar dapat berlangsung secara efektif dalam mewujudkan tujuan pemebelajaran yang ingin dicapai diperlukan adanya keselaran antara materi ajar dengan media dan strategi dalam pembelajaran. Keterpaduan pengajaran bukan hanya antara komponen - komponen proses belajar mengajar tetapi juga antara langkah yang satu kelangkah berikutnya. Namun dalam menyusun program kegiatan pembelajaran guru juga harus memperhatikan kondisi sekolah terutama tersedianya sarana dan prasarana dan alat bantu pelajaran, selanjutnya guru juga memperhatikan kemampuan dan perkembangan siswa dengan cara memperhatikan aktivitas belajar siswa dan menyesuaikan metode dan bentuk kegiatan mengajar. Didalam memilih media pembelajaran guru juga harus mempertimbangkan seberapa jauh media tersebut ampuh mengembangkan kemampuan atau perilaku yang tekandung dalam rumusan tujuan pembelajaran yang akan dicapai. Disamping itu pemilihan materi pembelajaran juga harus memperhatikan kesesuaian dengan tingkat pendidikan/ perkembangan siswa pada umumnya dan juga teroganisasi secara sistematik dan berkesimanbungan.

\section{Penilaian Pembelajaran}

Salah satu manfaat hasil penilaian hasil belajar adalah untuk memberikan umpan balik kepada semua peserta didik, baik secara langsung maupun tidak langsung. Umpan balik dapat dijadikan sebagai alat bantu guru untuk membantu peserta didik agar kegiatan belajarnya menjadi lebih baik dan meningkatkan kinerjanya.Umpan balik tersebut dapat dilakukan secara langsung, tertulis atau demonstrasi. Dalam memberikan umpan balik, guru hendaknya memperhatikan kualitas pekerjaan peserta didik dan tidak membandingkannya dengan hasil pekerjaan peseta didik lainnya.

\section{SIMPULAN}

Hasil penelitian ini dilakukan secara kualitatif. Berdasarkan data yang diperoleh dari wawancara, observasi dan dokumentasi tentang Profil Kinerja Guru Profesional, dapat disimpulkan bahwa:

1. Kinerja guru profesional di MTs Negeri 3 Pekanbaru ini sebenarnya sudah baik dalam membuat dan merancang perangkat pembelajaran, hal ini dapat dilihat dari hasil wawancara, observasi dan dokumentasi yang sudah sesuai dengan modul yang diberikan oleh kementerian pendidikan dan kebudayaan pada saat pelatihan yang diselenggarakan disekolah induk masing-masing walaupun masih ada beberapa orang guru profesional yang melakukan berapa kesalahan dalam merumuskan indikator pembelajaran dan menggunakan strategi pembelajaran yang tidak sesuai dengan isi dari perangkat pembelajaran dan juga dalam penulisan alokasi waktu disilabus ditemukan beberapa kesalahan. Seharusnya alokasi waktu yang dituliskan untuk satu kali pertemuan gunanya agar guru dapat dengan mudah mengetahui batas pelajaran yang telah diberikan kepada peserta didik.

2. Guru profesional di MTs Negeri 3 Pekanbaru dalam melaksanakan kegiatan pembelajaran sudah cukup baik dalam memperhatikan kesesuaian materi dan strategi/ metode dalam pengajaran walaupun ditemukan beberapa orang guru profesional yang menggunakan model/pendekatan pembelajaran yang tidak sesuai dengan langkah pembelajaran yang dipilihnya. Didalam memilih media pembelajaran guru juga mempertimbangkan seberapa jauh media tersebut ampuh mengembangkan kemampuan atau perilaku yang terkandung dalam rumusan tujuan pembelajaran yang akan dicapai. Disamping itu pemilihan materi pembelajaran juga harus memperhatikan kesesuaian dengan tingkat pendidikan/ perkembangan siswa pada umumnya dan juga teroganisasi 


\title{
JURNAL
}

\section{MANAJEMEN PENDIDIKAN Vol. 5 No.2 Maret 2021: pp.61-66}

\author{
PENELITIAN KUALITATIF
}

secara sistematik dan berkesimanbungan. Didalam pembuatan media pembelajaran guru juga sering melibatkan peserta didik dengan tujuan guru disini dapat melihat pemahaman siswa dan keterampilan siswa dalam membuat media untuk pembelajaran yang mereka pelajari.

3. Didalam memberikan penilaian masih terdapat beberapa orang guru profesional di MTs Negeri 3 Pekanbaru yang menggunakan LKS sebagai bank soal bukan menilai pemahaman siswa sesuai dengan materi yang baru disampaikan. Hal ini dapat dilihat dari lampiran penilaian yang ada di RPP tidak sesuai dengan latihan yang diberikan guru kepada siswa. Seharusnya guru profesional memberikan penilaian pada akhir pembelajaran dan juga terhadap proses pengajaran itu sendiri karena dengan penilaian dapat dilakukan revisi desain pengajaran dan strategi pengajaran. Penilaian juga dapat berfungsi sebagai bahan acuan kita untuk melihat keberhasilan kita dalam menyampaikan materi dan dalam mennggunakan strategi pembelajaran. Itu sebabnya, penilaian menempati kedudukan penting dalam rancangan kurikulum dan rancangan pengajaran.

\section{DAFTAR PUSTAKA}

Moleong, Lexy J. 2013. Metode Penelitian Kualitatif. Edisi Revisi. Bandung : PT.

Remaja Rosdakarya.

Nana Syaodih S. 2003. Perencanaan Pengajaran, Jakarta, Rineka Cipta.

Supardi,2013. Kinerja Guru. Jakarta. Raja Grafindo Husada. 